\title{
The Role of Foreign Direct Investment Towards the Goal of Sustainable Development: Underscoring the Need for A Regulatory Policy Approach in Developing Countries
}

\author{
M. Rafiqul Islam \\ Emeritus Professor, Department of Law, Macquarie University, Australia
}

\section{INTRODUCTION}

Foreign direct investment (FDI) has a developmental role in capital and technology impoverished developing countries. FDI remains their largest and most sought-after external source of finance for economic development. Liberalised entry, speedy facilitation, incentivised operation, and investor-state dispute settlement (ISDS) under bilateral investment treaties (BITs) are the common features of FDI governance policy today. As more countries compete for FDIs, its domestic regulation has become more promotional with attractive fiscal and non-fiscal incentives and less policing. This trend has implications for the economic sovereignty and development of most host developing countries. A blankly incentivised FDI policy does not necessarily protect their FDI-induced economic interest. Generally, BIT led FDI governance and ISDS afford caveats that militate in favour of protecting corporate interests more often than the competing interest of host developing countries. As a result, some host developing countries, notably Bolivia, Ecuador, Venezuela, Australia, India, and others, which once followed open and liberal FDI policies, now impose stringent regulatory restraints and pursue diverse FDI policy approaches to protect their national interests. ${ }^{1}$

Recent record of the UN Conference on Trade and Development (UNCTAD) reveals that after its record rise worldwide in 2015, FDI flow in 2016-18 has declined globally though flows to developing countries remain stable; and a substantial amount of FDIs between developing countries is actually owned by multinational corporations (MNCs) of developed countries. ${ }^{2}$ Even when FDI growth was at its peak in 2015, that growth failed to bring an equivalent economic development in host developing countries, which alarmed the UN Secretary-General. In his preface to the UNCTAD Report 2016, he cautioned that 'this growth [in 2015] did not translate into an equivalent expansion in productive capacity in [host] countries' and urged parties to follow the Addis Ababa Action Agenda 2015 'for reorienting ... FDI towards sustainable development ... to leave no one behind and build a world of dignity for all'. ${ }^{3}$ Signs of further

1 M Sornarajah, The International Law on Foreign Investment (3rd edn, Cambridge University Press 2010) 59; Karl Souvant, 'FDI Protectionism is on the Rise' (2009) World Bank Policy Research Working Paper No. 5052.

2 UNCTAD, World Investment Report 2019 (UN Doc. UNCTAD/WIR/2019) x, xi.

3 UNCTAD, World Investment Report 2016 - Investor Nationality: Policy Challenges (UN Doc. UNCTAD/WIR/2016); the Addis Ababa Action Agenda on Financing for Development was adopted 
marginalisation of FDI-induced sustainable development due to the intrusion of 'digital divide' are evident in UNCTAD World Investment Report 2017.

The premise of this article is the above concern of the UN Secretary-General on the lopsided outcomes of FDIs. It critically examines the prevailing international policy framework pertaining to FDI to highlight the underlying reasons of such outcomes. It argues that the peripheral policy approach to the developmental role of FDI has led to the perennial problem of asymmetrical protection for FDI at the expense of the competing interest of host developing countries. This failure in effect hamstrings the pursuit of FDI-induced development in these countries. Both foreign investors and host countries engage in FDI activities to maximise their competing interests. The former seeks to maximise FDI-induced profit-making, while the latter needs FDI for economic development. The liberalisation and regulation of FDI therefore must co-exist pragmatically to balance these competing interests. If host countries need to be FDI protection-friendly, FDI must reciprocate by being development-friendly. The ailing post-war pro-investor policy warrants a searching reappraisal with a view to develop an inclusive global policy framework for the 21 st century. Such a policy must accommodate a liberalised FDI market for investors and the regulatory right of host countries to ensure their sustainable development goal to face the challenge of the 2030 agenda. A balanced policy based FDI governance supporting the goal of sustainable development has the potential to minimise uncertainty and maximise predictability of FDI contributions, a win-win for both stakeholders.

The existing orthodox policy of a highly liberalised FDI regime compels developing countries to make a precarious trade-off between attracting FDIs and maintain control to derive benefits. This article argues for a liberalised FDI environment with a development-focused regulatory approach in which host developing countries can define their national interest test for incoming FDI screening to achieve its purpose. It recommends that various internal non-commercial risk to FDI in many developing countries undermine commercial certainty. These risks need to be addressed by improving law and order free from political unrests, professional administration free from red-tapes and corruption, infrastructure for cost-efficient transportation and market access, technology-based facilitation at the custom, and effective local judicial remedies. These internal reforms may be more palatable than regulatory relaxation to present developing countries as attractive FDI destinations. The partisan liberal and neoliberal push for further FDI liberalisation and facilitation is now ongoing at the World Trade Organization (WTO). If such push persists unabated, regulatory restraint on FDIs inimical to the national interest and security will continue to remain a necessity in many host developing countries.

\section{ECONOMIC RATIONALES OF INTERNATIONAL FDI POLICY}

by the Third International Conference on 13-16 July 2015 in Addis Ababa and endorsed by UNGA Res 69/313 (27 July 2015).

${ }^{4}$ UNCTAD, World Investment Report 2017 (UN Doc. UNCTAD/WIR/2017) xiv. 


\section{A. Liberalism in FDI policy: its birth and bloom}

The international FDI policy regime prior to the Second World War ensured the full imperial control over the natural and human resources of the colonised world. ${ }^{5}$ The interwar period witnessed the policy of dogmatic nationalism, excessive economic rationalism, and aggressive protectionism that created insurmountable barriers to the cross-border movement of FDIs. The post-war FDI regime reversed the inwardlooking policy to an outward-looking liberal policy and became a vehicle for the recovery and reconstruction of the world economy devastated by the war. The US was the only economy with substantial surplus capital sought-after by capital-deficit economies. For the uninterrupted free flow of its capital across the world, the US required and pursued market liberalisation with no economic frontiers. Its post-war economic thoughts were heavily dominated by Adam Smith's Wealth of Nations and economists relentlessly campaigned for the virtues of free capital market. The liberalised FDI market was shown as the efficient manager of the world economic recovery by virtue of its self-regulatory capacity to determine the elasticity of competition in free market conditions. With its surplus capital and no restrictions on cross-border movement of capital, the US facilitated the creation of MNCs to manage the cross-border flow of capital. This is how there emerged a liberalised global FDI market dominated by MNCs as the institutionalised foreign investors. ${ }^{6}$ Deregulation, freedom of contract, privatisation, and private property protection became the main economic rationales of this liberalised FDI policy, which had manifestly anchored in the immediate post-war period and remains at the epicentre of the global FDI policy regime today. ${ }^{7}$

The UN was established in 1945 as a global organisation with political and economic agendas. UN members have pledged 'international economic cooperation' under Chapter IX of the UN Charter. This economic cooperation of UN members was replaced by the 'competition' element of the post-war FDI-led economic recovery policy. The UN decolonisation process prior and after the 1960s conferred statehood on many colonies, which are mostly developing countries. These new countries lacked capital, technology, and skill necessary for post-independence development owing to their prolonged exploitation by the colonial powers. Consequently, they had to import foreign capital, technology, and know-how in the form of FDI as a catalyst for economic development. This is how FDIs have assumed an important developmental role in host developing countries. These countries increasingly pursue their nationbuilding venture of development, which has resulted in an exponential increase in their demand for FDIs. This increased demand for FDI has led each country to compete with

5 Kate Miles, The Origins of International Investment Law: Empire, Environment, and the Safeguarding of Capital (Cambridge University Press 2013) part I.

6 Rainer Hellmann, The Challenge to US Dominance of the International Corporation (Dunellen Publications 1970); Raymond Vernon, Sovereignty at Bay: The Multinational Spread of US Enterprises (Basic Books 1971).

7 Kenneth Vandevelde, 'Sustainable Liberalism and the International Investment Regime' (1998) 19 Michigan International Law Journal 375-85; John Conybeare, United States Foreign Economic Policy and the International Capital Markets (Routledge 1919). 
the rest to attract more and more FDIs, culminating into a covert competition of more incentivised liberalised national FDI policy and less policing to augment inbound FDI inflow - a race to the bottom.

\section{B. Neoliberalism in FDI policy: expanding the 'transnational capitalist class'}

The current global FDI policy of market liberalism represents the economic conditions of few post-war western industrialised countries. It is not based on an epistemological appreciation of the economic conditions of the rest of the world. The marginalised economic plight of the impoverished underdeveloped world was beyond the mindset of post-war economic policymakers. The narrowly focused Euro-centric economic recovery plan (both the Bretton Woods and Marshall Plans) took no account of the special economic plight of FDI importing host countries; indeed, many of them did not exist then. The existing policy framework within which FDIs operate continues to pursue increasing liberalisation, which appears to be a mature manifestation of the post-war liberalism imposed on developing countries. The current global FDI regime, being rooted in post-war liberal market policy, has introduced a web of rules and policies that overtly militate in favour of corporate interest, which has paved the emergence of a new 'transnational capitalist class' free from any jurisdictional restrictions and yielding decisive economic power to undermine the 'social contract between the state and citizens'. ${ }^{8}$

MNCs now have the power to influence national resource allocation and exploitation, which has been transferring many national economic activities from public to private sector regardless of their detrimental effects on the socio-political needs and economic priorities of a developing country. These powerful market players threaten many host developing countries with the fear of capital flight to avoid any regulatory intervention curtailing corporate freedoms. The traditional role of host developing countries as the provider of social welfare and public goods and the protector of human rights of their own citizens is now eclipsed under the shadow of their role as FDI market liberalisers. This neoliberal FDI environment is the new global policy paradigm of FDI. It is this policy that has steadily cascaded down in most host developing countries to limit their regulatory space and the jurisdiction of their domestic judiciary. ${ }^{9}$

In recent time, successive attempts have been made to widen and implement neoliberal FDI law and policy. The first institutionalised attempt to circumvent the host country's authority was the high-profile OECD Multilateral Agreement on Investment (MAI) 1998, which failed following widespread public protests in developed and developing

8 Justin Schwartz, 'Neoliberalism and the Law: How Historical Materialism Can Illuminate Recent Governmental and Judicial Decision Making' (2013) 22 New Labour Forum 71, 77; David Harvey, A Brief History of Neoliberalism (OUP 2005) 152, 154.

9 Louis Turner, Invisible Empire: Multinational Companies and the Modern World (Harcourt Brace Jovanovich 1971); Stephen Hymer and Robert Rowthorn, 'Multinational Corporations and International Oligopoly: The Non-American Challenge' in Charles Kindleberger (ed), The International Corporation: A Symposium (MIT Press 1970) ch 3; Jonathan Moran, 'The Dynamics of Class Politics and National Economies in Globalisation: Marginalisation of the Unacceptable' (1998) 22(3) Capital and Class 53-83.

Page $\mid 210$ 
countries alike. ${ }^{10}$ The next attempt was the Trans-Pacific Partnership (TPP) 2015 on 'investment' and ISDS in chapter 9. Its overarching definition encompasses almost every significant component of the social infrastructure of 11 signatory states and extends far beyond the protection of private property to include 'speculative financial instruments, government permits, intangible contract rights, intellectual property right and market share' (section A). ${ }^{11}$ Its ISDS provisions expose state parties to investorinitiated claims for the breach of minimum standard of treatment, prompting some states to reform their laws to weaken environmental protection. ${ }^{12}$ Its "Minimum Standard of Treatment' accords 'fair and equitable treatment and full protection and security' to investments (Art 9(6)(1)), which exposes a party to lawsuits for breaching minimum standard of treatment obligation caused by 'an action that may be inconsistent with an investor's expectations ${ }^{2}{ }^{13}$ The TPP investment regime regards capital as the most sacred that requires strict legal protection; but makes no reference whatsoever to any quantifiable or indicative contribution that an investment may make to the host economy.

Neoliberalism has also gained momentum in the form of a new WTO investment facilitation framework. The stalled debate over such a framework has been resuscitated at the WTO Ministerial Conference in 2017. Some developing countries, notably China, Brazil, Argentina, Mexico, and South Korea, have become sources of outward FDI and been pressing for a WTO investment facilitation framework to further simplify and liberalise the FDI approval procedures for speedy entry. The Economic Community for West African States and WTO Friends of Investment Facilitation for Development organised the Abuja High Level Trade and Investment Facilitation Forum for Development in 2017 to press African countries to support a WTO investment facilitation agreement. ${ }^{14}$ This shifting posture of major developing countries with surplus capital on the negotiation of a WTO investment facilitation framework has reinvented the link between multilateral trade and investment regimes under the WTO. The idea of an 'investment facilitation agreement for development' at the WTO was first coined in 2015 under the E15 Initiative by International Centre for Trade and Sustainable Development (ICTSD) and the World Economic Forum (WEF)

10 MAI text adopted on 24 April 1998; M Rafiqul Islam, International Trade Law (Law Book Co 1999) 257-65.

11 Australian Department of Foreign Affairs and Trade (DFAT), TPP Text and Associate Documents (Canberra, 6 October 2015) Annex 9-D; Patricia Ranald, 'The Trans-Pacific Partnership Agreement: Reaching Behind the Border, Challenging Democracy' (2015) 26 Economic and Labour Relations Review 241.

12 Centre for International Environmental Law (CIEL), The Trans-Pacific Partnership and the Environment: An Assessment of Commitments and Trade Agreement Enforcement (November 2015) 10; Public Citizen's Global Trade Watch, Case Studies: Investor-State Attacks on Public Interest Policies (Washington DC) <https://www.citizen.org/sites/default/files/egregious-investor-stateattacks-case-studies_4.pdf> accessed 10 June 2020.

13 CIEL (n 12) 106.

14 WTO, Deepening Africa's integration in the global economy through trade and investment facilitation for development- Abuja statement in the Ministerial Conference (7 November 2017) WTO Doc. WT/MIN (17)/4 WT/GC/186. 
to support the achievement of sustainable development objectives. ${ }^{15}$ Parallelly, a group of high, upper-middle, and middle income developing members calling themselves as 'friends of investment facilitation for development' (FIFD) headed by China and MIKTA Group launched informal discussions in April 2017 on investment facilitation for development in the WTO. ${ }^{16}$ A coalition of 70 WTO members co-sponsored a joint ministerial expression of interest at the WTO Ministerial Conference in Buenos Aires in December 2017 to engage in 'structured discussions' with the objective of adopting a multilateral framework on investment facilitation at the 12th WTO Ministerial Conference in Kazakhstan in June 2020 but suspended due to the Covid-19 outbreaks and is rescheduled to be held in Geneva on 30 November - 3 December 2021. ${ }^{17}$

The relationship between trade and investment was one of the four Singapore issues raised by developed members in the first WTO Ministerial Conference in 1996 gained no support from developing members. The Singapore Ministerial Declaration 1996 expressly provided that future negotiations on any Singapore Issues would take place only after an explicit consensus decision is taken among WTO members. ${ }^{18}$ This requirement of explicit consensus was successively reaffirmed and reiterated in the Doha Ministerial Declaration 2001, ${ }^{19}$ Cancun Ministerial Conference 2003, ${ }^{20}$ July 2004 Package ${ }^{21}$ and Nairobi Ministerial Declaration 2015. ${ }^{22}$ The proposal for a WTO investment facilitation framework suffers from a mandate crisis for want of an explicit consensus. Many WTO members openly oppose it arguing that the inclusion of this new issue will obscure and detract the WTO from advancing long overdue negotiations on the priority issues emanating from the Doha Development Agenda. ${ }^{23}$

15 ICTSD, 'Crafting a Framework on Investment Facilitation' Policy Brief (June 2018) 2; Ana Novik and Alexandre Crombrugghe, 'Towards an International Framework for Investment Facilitation' (OECD Investment Insights, April 2018) 1.

16 FIFD consists of 11 WTO members: Argentina, Brazil, Chile, China, Colombia, Hong Kong, Kazakhstan, Korea, Mexico, Nigeria, and Pakistan; MIKTA is an informal partnership between Mexico, Indonesia, South Korea, Turkey, and Australia.

17 Joint Ministerial Statement on Investment Facilitation for Development, Eleventh WTO Ministerial Conference, Buenos Aires (13 December 2017) WTO Doc. WT/MIN (17)/59; 12th WTO Ministerial Conference <https://www.wto.org/english/thewto_e/minist_e/mc12_e/mc12_e.htm> accessed 26 November 2021.

18 WTO, 'Singapore Ministerial Declaration' (WTO Website, 13 December 1996) para 20 <https://www.wto.org/english/thewto_e/minist_e/min96_e/wtodec_e.htm> accessed 23 May 2020.

19 WTO, 'Doha Ministerial Declaration' (WTO Website, 14 November 2001) para 20 <https://www.wto.org/english/thewto_e/minist_e/min01_e/mindecl_e.htm\#tradeinvestment> accessed 23 May 2020.

20 Robert Baldwin, 'Failure of the WTO Ministerial Conference at Cancun: Reasons and Remedies', (2006) 29(6) World Economy 677-696; Khor, Martin Khor, 'An Analysis of the WTO's Fifth Ministerial Conference' <https://www.g24.org/wp-content/uploads/2016/01/Session-2_5.pdf> accessed 29 May 2020.

21 Package 2004, Art 1(g), <https://www.wto.org/english/tratop_e/dda_e/dda_package_july04_e.htm> accessed 21 May 2020.

22 WTO, 'Nairobi Ministerial Declaration' (WTO Website, 19 December 2015) preamble para $3<$ https://www.wto.org/english/thewto_e/minist_e/mc10_e/mindecision_e.htm> accessed 24 May 2020.

23 WTO, 'Ministerial Conference Statement by Members and Observers at the Plenary Session of the Eleventh Session of the Ministerial Conference' (WTO Website, 9-13 December 2017)

Page | 212 
The push for neoliberalism in investment has come at a time when multilateral economic cooperation has reached its rock bottom level at the WTO, which is increasingly sidelined by national and regional protectionism. Its very existence faces increasing uncertainties in the face of continuous outbreaks of trade wars, tit-for-tat arbitrary imposition of tariffs, sanctions, and quotas between the US and China in which the WTO has become a helpless spectator. Powerful members consistently defy the WTO rules with impunity. The new 'America first' among many protectionist policies contradict and undermine economic multilateralism. In December 2019, the Trump Administration blocked the appointments of new judges to the WTO Appellate Body to replace those who retired, which effectively has paralysed the ability to settle disputes. ${ }^{24}$ The trying times for the WTO has further been compounded by the premature resignation of its Director General on 31 August 2020, one year before the expiry of his tenure. ${ }^{25}$

Investment liberalisation through speedy entry facilitation is not enough for host developing countries, which need FDI for their economic development. So, entry screening for selection and subsequent national regulation of the operation of FDIs in their national interest must be included in any negotiation for an investment facilitation framework at the WTO. Otherwise, such a framework with expansive right of entry would tilt the balance further in favour of investors. It is yet another neoliberal pressure to liberalise the international FDI regime more for the benefit of newly emerged capital exporting developing countries which opposed such an agreement in 2003 when they did not have sufficient outward investment. Now they are looking for bringing investment under the 'single undertaking' of the WTO for the mandatory enforcement of easy or unrestricted FDI frontiers to maximise the benefits of their surplus capital. The operation of neoliberalism is solely devoted to the unrestricted cross-border movement of capital and its flourishment to the exclusion of competing interests of capital importing countries to preserve their public policy space, welfare, and environmental considerations. FDI operation within this neoliberal systemic value is likely to result in outcomes maligning for economic benefits and sovereignty, a forewarning for host developing countries desirous of relying on FDI for their

<https://www.wto.org/english/thewto_e/minist_e/mc11_e/mc11_plenary_e.htm> accessed 24 May 2020; 'Minutes of the meeting held in the Centre William Rappard on 10 and 18 May 2017' <https://docs.wto.org/dol2fe/Pages/FE_Search/DDFDocuments/237843/q/WT/GC/M167.pdf> accessed 24 May 2020.

24 Aditya Rathore and Ashutosh Bajpai, 'The WTO Appellate Body Crisis: How We Got Here and What Lies Ahead' (Jurist 14 April 2020) <https://www.jurist.org/commentary/2020/04/rathore-bajpai-wtoappellate-body-crisis/> accessed 29 May 2020; Keith Johnson, 'How Trump May Finally Kill the WTO' (Foreign Policy, 9 December 2019) <https://foreignpolicy.com/2019/12/09/trump-may-killwto-finally-appellate-body-world-trade-organization/> accessed 29 May 2020; 'US blocks appointment of WTO judges' (New Europe, 10 December 2019) <https://www.neweurope.eu/article/ us-blocks-appointment-of-wto-judges/> accessed 29 May 2020.

25 Elena Pavlovska, 'WTO chief Azevedo resigns amid appeal dispute with US' (New Europe, 15 May 2020) <https://www.neweurope.eu/article/wto-chief-azevedo-resigns-amid-appeals-dispute-withus/> accessed 29 May 2020; 'WTO director-general announces surprise resignation amid trying times for trade' (Global Trade Review, 14 May 2020) <https://www.gtreview.com/news/global/wtodirector-general-announces-surprise-resignation-amid-trying-times-for-trade/> accessed 29 May 2020. 
sustainable development.

\section{INTERNATIONAL FDI REGULATORY POLICY}

\section{A. Fractured public international law regulation: a victim of North-South conflicts}

Strictly speaking, there is no international law, principle, or convention that specifically govern FDI operation. The International Court of Justice (ICJ) held that there is "no generally accepted rules in the [investment] matter have crystallised on the international plane' ${ }^{26}$ The ownership of and control over vast amounts of world's economic resources has made MNCs the champions in setting the global economic agenda. But MNCs have no international legal personality and their status is the same as that of citizens, determined by the law and under the jurisdiction of their respective country of incorporation. ${ }^{27}$ MNCs are privately funded profit-making commercial entities which generally conduct their business beyond any inter-state cooperation and agreements and hence they are not 'subject' and 'person' in international law.

FDI presupposes that MNC investors engage in and operate their business in foreign countries. As a result, the link between their FDIs operation and the country of incorporation is too remote and has no effect on its MNCs in foreign countries. Moreover, MNCs' FDI profits are a major source of revenue earnings for the incorporating countries, which are usually sympathetic and pliable to corporate will. It is this vested interest of the incorporating countries that militates against the adoption of an internationally agreed-upon regulatory policy for MNCs. MNCs conduct their business globally through an integrated network of offshore subsidiaries and affiliates, which keep them beyond regulatory reach. ${ }^{28}$ Since MNCs lack locus standi before international law, they can conduct their businesses on the international stage without the regulatory grip of international law. Their FDI operations in free market conditions, global mobility, and freedom of FDI flight make them unamenable to the control of host developing countries. Hence, the combined effect of lacklustre regulation of incorporating countries, no status in international law, and inability of host developing countries to regulate has enabled MNCs to conduct FDIs free from any regulatory intervention. $^{29}$

The lack of a consensual global policy for the regulation of MNCs is also attributable to the North-South conflict of economic interests between the FDI-exporting and FDI-

26 Barcelona Traction case (Belgium v Spain) [1970] ICJ Rep 47; ELSI case (US v Italy) [1989] ICJ Rep 15; Diallo case (Guinea v Democratic Republic of the Congo) [2010] ICJ Rep 639.

27 Barcelona Traction Case (n 26) 42.

28 Michele Rioux, 'Multinational Corporations in Transnational Networks: The Theoretical and Regulatory Challenges in Historical Perspective' (2014) 4(3) Open Journal of Political Science 109117; Beibei Dong et al, 'Factors that Influence MNCs' Control of their Operations in the Foreign Markets: An Empirical Investigation' (2008) 16(1) Journal of International Marketing 98-116.

29 ILC, 'Report of the International Law Commission on Draft Articles on Responsibility of States for Internationally Wrongful Acts 2001' (2001) UN Doc. A/56/10, Arts 57-58; Donald Lecraw, 'Bargaining Power, Ownership, and Profitability of Transnational Corporations in Developing Countries' (1984) 15 Journal of International Business Studies 27-43.

Page | 214 
importing countries. While the former strongly support free FDI market for MNCs, the latter encounters continuous erosion of their sovereign right to manage their economic affairs to serve national interest. It is this intense polarisation that has stultified all attempts at reaching a consensus-based international regulatory policy for MNCs. However, these attempts have resulted in some codes of conduct and guidelines for the regulation of FDI operations. The UN Centre on Transnational Corporations and UNCTAD, both dominated by FDI-importing countries, have formulated a code of conduct for FDI business practices of MNCs to protect the interest of host countries. The OECD and World Bank, both dominated by FDI-exporting countries, have developed a code of conduct and Guidelines respectively to protect FDIs and MNCs in host countries. These codes and guidelines are voluntary, diametrically opposite to each other, and self-contradictory entailing no binding policy option. This fragmented global policy allows MNCs to exploit an unregulated FDI market to maximise corporate interest.

\section{B. Private international law regulation: sowing the seeds of contradictions}

During the colonial era, the national resources of colonies were exploited through FDIs mostly by the colonial powers. In the immediate post-decolonisation period, the UN adopted a declaration on the 'permanent sovereignty over natural resources' ${ }^{30}$ in 1962 proclaiming the state ownership of and control over the natural resources. Newly emerged decolonised developing countries felt the urgency of exploiting their leftover natural resources for development. In response to this necessity and encouraged by the UN declaration, these countries embarked on widespread nationalisation of FDIs in the 1960s and 1970s. This wave of nationalisation became a cause of concern for foreign investors who were unwilling to invest in the absence of FDI protection. As a result, these countries felt the adverse effect of steady decline in FDIs on their economies, which compelled them to provide adequate FDI protection through bilateral and multilateral contracts concluded under private international law. One of such protection measures is bilateral investment treaties (BITs) with pre-determined ISDS mechanisms, predominantly binding international arbitrations between investors and state.

BITs are bilateral contracts between countries to provide mandatory protection to each other's FDIs in their territories. These contracts are negotiated between the parties reflecting their commercial consideration, FDI needs, economic status, political conditions, currency strength and convertibility, cheap labour availability, corporate tax incentives, and relative bargaining strength. Textually, BIT provisions are meant to promote and protect two-way FDIs but in reality FDIs usually flow in only one direction from capital-exporting developed and major developing countries to capitalimporting developing countries. Dictated by their urgent need for FDIs and inferior bargaining power, capital-importing countries often consent to overly imposing BITs skewed to protect FDIs with no explicit guarantee of economic benefits.

30 UN GA Res 1803 (XVII) (14 December 1962); Karol Gess, 'Permanent Sovereignty over Natural Resources: An Analytical Review of the United Nations Declaration and Its Genesis' (1964) 13(2) International and Comparative Law Quarterly 398-449. 
International arbitration, a quasi-judicial mechanism, is the main form of ISDS for resolving FDI disputes arising under BITs. FDI operation in host countries has both advantages and disadvantages, supporters and doubters. The socio-economic impacts and political considerations of FDI can generate public interests and concerns. The settlement of these domestic issues and concerns in privately organised ISDS arbitration without the involvement of national judiciary can create jurisdictional conflict. Conflicting interpretations and arbitral awards on the same point of law and fact are a distinct possibility when they are decided by different ISDS arbitrations and arbitrators. There is no higher arbitration chamber with appeal jurisdiction to resolve these contradictions. ${ }^{31}$ Unlike ISDS arbitration, it is the availability of appeal in domestic courts that offers remedies to the disputant parties to overcome or correct contradictory interpretations and judgments. These 'jurisdictional conflict and interpretive inconsistency' ${ }^{32}$ are inevitable when FDI disputes, being essentially domestic falling within the purview of the domestic law and judiciary of host countries, are resolved internationally by ISDS arbitration. The UNCTAD International Investment Arbitration Issues Note, 'Reform of Investor-Sate Dispute Settlement: In Search of a Roadmap' criticises the arbitral decisions (a) that 'have exposed recurring episodes of inconsistent findings', including 'divergent legal interpretations of identical or similar treaty provisions as well as differences in the assessment of the merits of cases involving the same facts', which has resulted in not only 'uncertainty about the meaning of key treaty obligations and lack of predictability of how they will be applied in future cases', but also 'erroneous decisions' ${ }^{33}$ The grounds for annulment enumerated in the ICSID Convention do not allow for 'manifest errors of law' but only on what could be considered procedural grounds (Art 52(1)).

The competing interests of investors in profit maximisation and host countries' maximisation of development can give rise to conflict of interests that sometimes lead to disputes. Foreign investors prefer and use international arbitration, as opposed to national courts of host countries, a trend that is seemingly building momentum due to the continuing influence of neoliberal policy on FDI governance. This trend has implications for the economic sovereignty and development of host developing countries. They invariably show their reluctance to regulate for fear of FDI flight. Amid this lacklustre domestic regulation, international arbitration is becoming a dominant ISDS mechanism under which cases have been soaring with massive compensation liability for host developing countries. These countries need to be more

31 Susan Franck, 'The Legitimacy Crisis in Investment Treaty Arbitration: Privatizing Public International Law through Inconsistent Decisions' (2004-2005) 73 Fordham Law Review 1521-22; William Park and Alexander Yanos, 'Treaty Obligations and National Law: Emerging Conflicts in International Arbitration' (2006) 58(2) Hastings Law Journal 251-98.

32 Doug Jones, 'The Problem of Inconsistency and Conflicting Awards in Investment Arbitration' (paper presented to German-American Lawyers' Association, Frankfurt, March 2011) <https://pdfs.semanticscholar.org/fb6f/302e99015ba3a1df0b7cbfaf8f3fa7cf2065.pdf> accessed 11 June 2020.

33 UNCTAD, 'Reform of Investor-State Dispute Settlement: In Search of a Roadmap' (No. 2, 26 June 2013) 3-4 <https://unctad.org/en/PublicationsLibrary/webdiaepcb2013d4_en.pdf> accessed 12 June 2020.

Page $\mid 216$ 
careful and measured in offering incentives in negotiating BITs to avoid exposure to exorbitant damage claims. Indeed, it is difficult for developing countries needing FDIs for development not to be succumbed to the unrelenting pressure of neoliberal capital market, which regards capital as sacred to be protected at all cost and, if necessary, coercively. ${ }^{34}$ Given the operation of ISDS arbitration dedicated to the profit-making drive of investors, host developing countries should approach ISDS arbitration to settle FDI disputes cautiously and accept it as the last resort, preferably after exhausting domestic judicial remedies.

\section{FDI DISPUTE SETTLEMENT POLICY}

\section{A. The World Bank Arbitration: a judge of its own cause}

BITs generally prescribe ISDS arbitrations as alternative to domestic courts or tribunals. The International Centre for the Settlement of Investment Disputes (ICSID) of the World Bank has become the dominant forum for ISDS arbitration. According to a UNCTAD report of December 2013, ICSID arbitrated 407 FDI disputes against 158 by UNCTRAL. ${ }^{35}$ This preference warrants a contextual and purposive analysis of ICSID. As noted, the nationalisation of FDIs scared investors, halted FDI flows, and reduced economic growth in many developing countries. This economic downturn reduced their World Bank/IMF debt-servicing capacity. In pursuit of recovering its loaned funds from debtor countries, the World Bank stepped in to revive a safe FDI environment by initiating a strong FDI protection regime in host countries.

Foreign investors and their incorporating countries rejected the domestic laws and courts of host developing countries in favour of international arbitration to settle FDI disputes. This rejection was attributable to: (a) the rights of host countries to their natural resources under the UN declaration on 'permanent sovereignty over natural resources', (b) weak application of rule of law, (c) inefficient legal systems with corrupt domestic courts, and (d) lacklustre law compliance and enforcement. ${ }^{36}$ Investors raised these concerns to record their 'no-confidence' in the domestic courts of host countries and favour ISDS arbitration instead. The World Bank sought to dispel these concerns by creating its own mechanism for FDI dispute resolution. This mechanism opted for private international law to avoid international and national law mechanisms. It created a self-contained arbitration process under ICSID to settle FDI disputes between host countries and private foreign investors, which entitled the parties to lodge FDI disputes directly to ICSID without recourse to the domestic law and

34 Andrew Ives, 'Neoliberalism and the Concept of Governance: Renewing with an Older Liberal Tradition to Legitimise the Power of Capital' (2015) 14 OpenEdition Journals (Online) <https://journals.openedition.org/mimmoc/2263> accessed 11 June 2020.

35 Patrick Carvalho, 'Investor-State Arbitration and the Rule of Law: Debunking the Myths' (Research Report No. 13, The Centre for Independent Studies, Sydney, April 2016) 6 <https://www.cis.org.au/app/uploads/2016/04/rr13-snapshot.pdf> accessed 11 June 2020.

36 Leon Trakman, 'Choosing Domestic Courts over Investor-State Arbitration: Australia's Repudiation of the Status Quo' (2012) 35(3) UNSW Law Review 984; Olivia Chung, 'The Lopsided International Investment Law Regime and Its Effect on the Future of Investor-State Arbitration' (2007) 47(4) Virginia Journal of International Law 956. 
judiciary of host countries. ICSID was created primarily to protect the debt-servicing interest of the World Bank and its creditors' FDIs by circumventing nationalisation and eliminating the alleged judicial bias and discrimination in host countries. ${ }^{37}$ The World Bank used ICSID as a carrot to encourage investors by affording reliable FDI protection through a dispute settlement outlet free from the control of host countries. It also used ICSID as a stick for debtor host countries with a veiled threat not to nationalise FDIs and risk the prospect of World Bank/IMF loans in the future.

The justification for ISDS arbitration under ICSID suffers from inconsistencies and contradictions. Foreign investors accrue a right to file a case against host countries for alleging breaches of contractual obligations under BITs. This arbitration process has no appeal process and host countries, aggrieved by any contradictory facts and/or erroneous interpretations of BIT arbitration clause/s, cannot challenge or appeal against ICSID arbitral awards. These arbitral awards are individualistic by nature and have no precedential effect on any future FDI disputes with similar facts and circumstances. ${ }^{38}$ These features of ICSID arbitration open a floodgate of interpretive inconsistencies and contradictory awards that militate against the crystallisation of ICSID arbitral jurisprudence and reliable interpretations of dispute resolution clauses under BITs. ICSID arbitrators are selected from a pre-determined list of qualified commercial litigators mainly from Europe and North America and about $95 \%$ of them are male. ${ }^{39}$ The Corporate Europe Observatory has found 'an elite 15' arbitrators (a) 'have captured the decision making in 55\% of the total investment treaty cases known today'; (b) are men from 'the rich North' who 'enjoy close links with the corporate world and share business' viewpoint in relation to the importance of protecting investors' profits'; and (c) unveil 'a dark irony' that these arbitrators, with close ties to the corporate world displaying their conflict of interest, decide on the 'issues that arise out of governments' implementation of policies to defend the public interest'. ${ }^{40}$

The conflict of interest is not a consideration in nominating ICSID arbitrators, who may even be the previous legal counsel for the investor party and they are not barred to be ICSID arbitrator in a subsequent dispute involving the same previous investor clients. ${ }^{41}$ This situation persists notwithstanding the ICSID Convention requirement that the arbitrators shall be persons who can 'exercise independent judgement' (Art 14(1)), UNCITRAL Rules 2010 providing the 'impartiality or independence' of

37 Leon Trakman, 'Investor-State Arbitration: Evaluating Australia's Evolving Position' (2014) 15(1) Journal of World Investment \& Trade 152, 162.

38 International Institute for Sustainable Development, Private Rights, Public Problems: A Guide to NAFTA's Controversial Chapter on Investor Rights (in association with World Wildlife Fund 2001) 85.

39 Chief Justice Robert French, 'ISDS: Litigating the Judiciary' (2015) 26 Public Law Review 155, 158, 161.

40 Corporate Europe Observatory 'Chapter 4: Who Guards the Guardians? The Conflicting Interests of Investment Arbitrators' (CEO Website, 27 November 2012), $<$ https://corporateeurope.org/trade/2012/11/chapter-4-who-guards-guardians-conflicting-interestsinvestment-arbitrators> accessed 11 June 2020.

41 Roderick Abbott et al, 'Demystifying Investor-State Dispute Settlement' (2014) 5 European Centre for International Political Economy 23; Jason Yackee, 'Investment Treaties and Investor Corruption: An Emerging Defense for Host States' (2012) 52(3) Virginia Journal of International Law 723.

Page $\mid 218$ 
arbitrators (Art 12(1)), and IBA Guidelines on Conflict of Interest in International Arbitration 2014 stipulating that the arbitrators must be free from potential conflicts of interest. The homogeneity of ICSID arbitrators in a heterogenous world with legal plurality and cultural diversity is the clearest yet explanation as to why the operational narratives of the ICSID arbitration process appears to be inherently biased towards investors and their FDIs. The Harten Study of 2012 examined ICSID awards and revealed their typical pro-investor and expansive claimant-friendly approaches, an 'approach [that] would be accentuated where the claimant was a national of a major Western capital-exporting state'. ${ }^{42}$

ICSID awards for compensation in favour of the winning party (usually investors) are excessively high. UNCTAD Study of 2015 showed that the investors of developed countries and their MNCs lodged 35 claims (out of total 42 claims) in 2014 and they gained significantly from ICSID compensatory awards. ${ }^{43}$ Its 2017 Report recorded no noticeable change in this trend. The total number of ISDS cases was 819 by November 2017, including 62 new cases initiated in 2016; 52\% cases decided in favour of the investors; $33 \%$ cases pending; and Australia and 15 Asian countries were sued for over $\$ 30$ billion. $^{44}$ Parties must pay for ICSID arbitration, which is cost-intensive - a questionable access to justice. According to OECD, the average cost of initiating arbitration is US\$ 8 million, ${ }^{45}$ which is affordable by only wealthier MNCs. Therefore, there is no reason to believe that the ISDS arbitration of FDI disputes under ICSID is impartial, apolitical, and objective.

ICSID arbitration available to foreign investors is not available to domestic investors of host countries and the latter is required to initiate investment disputes in domestic courts, a discriminatory competitive advantage in favour of foreign investors over their domestic counterparts. ICSID arbitration settles FDI disputes privately and confidentially beyond any public access or participation, which requires consent from both parties. Such consent is unlikely from the investors side particularly when a dispute involves host countries' public interest and policy, such as the environment, human rights, public health, green technology transfer, and corporate culture, and social responsibility. The confidentiality of ICSID arbitral proceeding is intended to avoid public scrutiny and reaction, public criticism and lobby, and potential challenge to compensatory award enforcements. ${ }^{46}$ More importantly, it is this narrowly focused

42 Gus Van Harten, 'Arbitrator Behaviour in Asymmetrical Adjudication: An Empirical Study of Investment Treaty Arbitration' (2012) 50(1) Osgoode Hall Law Journal 15.

43 UNCTAD, 'Recent Trends in IIAS and ISDS' (IIA Issues Note No 1, February 2015) 1, 6, 10 <http://unctad.org/en/PublicationsLibrary/webdiaepcb2015d1_en.pdf> accessed 12 June 2020.

44 UNCTAD, 'Investment Dispute Settlement Navigator' <http://investmentpolicyhub.unctad.org/ISDS> accesed 12 June 2020; 'The Hidden Costs of RCEP and Corporate Trade Deals in Asia' (Friends of the Earth, Australia, 2016) <http://www.foei.org/wpcontent/uploads/2016/12/The-hidden-costs-of-RCEP-and-corporate-trade-deals-in-Asia-FoEI.pdf> accessed 12 June 2020.

45 OECD, 'Investor-State Dispute Settlement: A Scoping Paper for the Investment Policy Community' (2012) Working Papers on International Investment 2012, No.03 by David Gaukrodger and Kathryn Gordon 19.

46 Mohsen al Attar, 'Reforming the "Universality" of International Law in a Globalizing World' (2013) 59(1) McGill Law Journal 97; Ciara Hackett, 'Accountability for Responsibility: An Assessment of 
confidentiality that keeps the public unaware of the extent and conditions of natural resource exploitation in host developing countries by MNC investors. ${ }^{47}$

International Chamber of Commerce (ICC) and UN Commission on International Trade Law (UNCITRAL) amended their ISDS arbitration rules in 2012 and 2014 respectively to ensure transparency, disclosure obligations, cost-effectiveness and time-efficiency in award-making, and improved public accessibility. ICSID has so far made no reform in its ISDS arbitration rules, nor is bound by the reformed case management standards of ICC/UNCITRAL. A UNCITRAL arbitral award is not binding when it is 'set aside or suspended by a court of the country [or] the recognition or enforcement of the award would be contrary to the public policy of this State' (Art $36(1 \mathrm{v})$ ). But all ISDS awards by ICSID arbitration are unequivocally conclusive and binding: "courts shall treat the award as if it were a final judgment of the courts of a constituent state' (ICSID Convention Art 54). The admissibility of arbitration claims under the ICSID Convention does not require investors to exhaust domestic remedies available in host countries as a precondition for the lodgement of arbitration petitions (Art 26).

\section{B. Disabled domestic courts of host countries}

Foreign investors invariable exclude the jurisdiction of the judiciary of host developing countries in favour of BIT-based ISDS arbitrations of FDI disputes. The foreign investors' perception that the domestic courts of host countries are biased and incapable of protecting investors' interests and upholding the rule of law is arguably based on sound questionable merit and legal validity. Nonetheless, in all fairness to them it is conceded for the sake of argument that their perception entails limited merit in some lower courts in certain host developing countries' jurisdictions due to timeinefficient, cost-ineffective, and corrupt practices. But the fact remains that even the highest courts' decisions in developed host countries have been unacceptable and ignored by foreign investors. The Australian Tobacco Plain Packaging Act 2011, to give an example, restricted the branding freedom of tobacco companies to reduce smoking and consequential lung cancer rate as a life-saving health measure. Cigarettes producing MNC Philip Morris Ltd regarded this health measure as a threat to its profitmaking and challenged the Tobacco Act in the High Court of Australia arguing that the Act expropriated its intellectual property (IP) right but the apex court found no expropriation of IP right by the Act. ${ }^{48}$ Incorporated in the US, Philip Morris restructured itself as a Hong Kong based company. Australia had a BIT with Hong Kong since 1993, which had an international arbitration clause. Philip Morris initiated

the Transnational Capitalist Class Role in Driving a Global CSR Agenda' (2012) 27(2) Australian Journal of Corporate Law 189, 189; Leslie Sklair, 'Capitalist Globalisation: Fatal Flaws and Necessity for Alternatives' (2007) 13(1) Brown Journal of World Affairs 29.

47 Susan Franck, 'The Legitimacy Crisis in Investment Treaty Arbitration: Privatizing Public International Law through Inconsistent Decisions' (2004-2005) 73(4) Fordham Law Review 1521; Amanda Norris and Katina Metzidakis, 'Public Protests, Private Contracts: Confidentiality in ICSID Arbitration and Cochabamba Water War' (2010) 15(3) Harvard Negotiation Law Review 31.

48 British America Tobacco Australasia Limited \& Others v Commonwealth of Australia (2012) HCA 43, 181.

Page $\mid 220$ 
an arbitration action on the same ground of IP right infringement that the Australian High Court had rejected before. The Permanent Court of Arbitration (PCA) in Singapore dismissed the action on a completely different ground. Philip Morris failed to prove that it was an Asia-based Hong Kong company and the PCA did not go ahead with the merit of the case for want of jurisdiction. ${ }^{49}$

The consequence of ISDS is easily discernible. Foreign investors can (a) challenge the law of sovereign host countries enacted by elected parliaments with no regard for the public interests; (b) invoke BIT-based ISDS arbitration to undercut the authority and legitimacy of a host country court decision, which is binding under the constitutional law; (c) pursue ISDS arbitration beyond the domestic jurisdiction pursuant solely to private international law different from the domestic law of host countries; (d) ignore any unfavourable decisions by host countries' court and submit the same dispute to ISDS arbitration; (e) trigger the settlement of a FDI dispute by two different judicial bodies under two different laws, producing two different interpretations and outcomes; and (f) get a host country court decision overruled by an ISDS arbitration award, which is not appealable and has no obligation to consider the host country court's interpretation, binding decision and persuasive judicial precedent. ${ }^{50}$ The advent of ISDS poses a threat to state sovereignty by 'shifting power from host countries' courts, whose authority is derived from their Constitution, to unaccountable ISDS tribunals' ${ }^{51}$

ISDS thus usurps the jurisdiction of local courts in favour of international arbitration. Host developing countries should be extremely careful in negotiating necessary safeguard provisions in BITs. These safeguards may inclusively include: favouring open arbitral proceedings over secretive arbitration rules and tribunal, requiring the availability of arbitration documents to the other party, choosing domestic judiciary as the ISDS forum and its exhaustion as a condition of initiating international arbitration as the last resort, setting a limit for potential damage claims, and avoiding any plea of 'commercial in confidence'. The scope of international arbitration may be restricted by precluding some sensitive areas of national interests, such as, public interest, welfare, and policy relating to health, occupational safety, human rights, industrial relations, the environment, fiscal interests, over-exploitation of natural resources, and land acquisition and resettlement. ${ }^{52}$ In this global free FDI market and mobility of MNC investors, it would be exceedingly difficult to carve-out the above sensitive areas of national significance from the realms of international arbitration. But it is worth trying to exclude as many areas inimical to national interest with an unequivocal

49 Philip Morris Asia Limited (Hong Kong) v Commonwealth of Australia (PCA Case No 2012-12 award of 17 December 2015) <https://www.pcacases.com/web/view/5> accessed 12 June 2020.

50 Jurgen Kurtz and Luke Nottage, 'Investment Treaty Arbitration "Down Under": Policy and Politics in Australia' (2015) 30(2) ICSID Review: Foreign Investment Law Journal 465, 472.

51 Elizabeth Warren, 'The Trans-Pacific Partnership Clause Everyone Should Oppose' The Washington Post (Washington, 25 February 2015) <https://www.washingtonpost.com/opinions/kill-the-disputesettlement-language-in-the-trans-pacific-partnership/2015/02/25/ec7705a2-bd1e-11e4-b274e5209a3bc9a9_story.html> accessed 12 June 2020.

52 Kyla Tienhaara, Expropriation of Environmental Governance: Protecting Foreign Investors at the Expense of Public Policy (CUP 2009); A Titi, The Right to Regulate in International Investment Law (Hart Publishing 2014). 
standard of specificity in BIT drafting to avoid ambiguity or expansive interpretations as a ploy to circumvent investors' obligations and initiate ISDS compensatory arbitration claims.

Notwithstanding its confidential and non-transparent proceedings, growing ISDS cases with their serious implications for the economies of host countries are increasingly felt worldwide. This has resulted in more public attention to and scrutiny of the effects of once an obscure feature of BITs, which impedes on economic sovereignty to the benefit of MNCs with no enforceable obligations to operate responsibly to socio-economic issues and public interests. Many FDI hosting countries, such as Australia, Indonesia, South Africa, India, the EU and Poland, are among those taking steps to revisit and renegotiate their BITs. Australia, being a developed economy, has been taking a cautious approach to the inclusion of an international arbitration clause in its BITs. The 2010 Research Report of the Australian Productivity Commission (APC) found no evidence to 'suggest that ISDS provisions have a significant impact on FDI flows' with 'few benefits and considerable risks' of an international arbitration clause in FDI treaty, which is an imminent challenge for the economic sovereignty of Australia. ${ }^{53}$ In April 2011, Australia adopted a policy of rejecting any ISDS provisions inimical to its sovereign authority to make policy and law to protect its national interest and social, environmental and economic policy-matters and would accept ISDS provisions conditionally upon evaluating their merits on a 'case-by-case basis'. 54

\section{NATIONAL REGULATION OF FDI TOWARDS THE GOAL OF SUSTAINABLE DEVELOPMENT}

FDI-induced development in host developing countries must be sustainable and synergised towards achieving the sustainable development goal (SDG) -10 of the UN to alleviate poverty and reduce inequality by 2030. An investment is considered 'sustainable' when it is:

[C]ommercially viable investment that makes a maximum contribution to the economic, social and environmental development of host countries and takes place in the framework of fair governance mechanisms. This definition goes beyond "do no harm" and calls for efforts on the part of foreign affiliates to make an active contribution to sustainable development. ${ }^{55}$

The developmental sustainability of FDIs is to be measured by its life-cycle

\footnotetext{
${ }^{53}$ APC, Bilateral and Regional Trade Agreements (Research Report, November 2010) xxv, 265, 271-74.

54 'Gillard Government Trade Policy Statement: Trading Our Way to More Jobs and Prosperity' (DFAT, Canberra, April 2011) 14; Thomas Faunce, 'Australia's Embrace of Investor State Dispute Settlement: A Challenge to the Social Contact Ideal?’ (2015) 69(5) Australian Journal of International Affairs 595, 597.

55 Karl Souvant and Howard Mann, 'Towards an Indicative List of FDI Sustainability Characteristics' (ICTSD and WEF, 2017) 2 <http://e15initiative.org/wp-content/uploads/2015/09/E15-InvestmentSauvant-and-Mann-Final-1.pdf> accessed 21 May 2020; Karl Sauvant, 'Determining Quality FDI; A Commentary on the OECD's "FDI Qualities Project" (Kluwer Arbitration Blog, 20 April 2018) $<$ https://papers.ssrn.com/sol3/papers.cfm?abstract_id=3376328> accessed 21 May 2020.
}

Page $\mid 222$ 
contribution to host counties, which does not occur automatically in an unregulated environment. It requires proactive policy intervention by involving multi-layered national authorities, regulators, and policymakers of a host country in the determination process of what is required of its sustainable development to support strategic domestic priorities in its national interest and public policy space. It necessitates the formulation of rules to quantify FDI contributions, investment objectives, process to identify quality of sustainable development, and consequences of failure to deliver. The sustainable developmental goals of developing countries are uniquely dissimilar due to their diverse socio-economic conditions warranting FDIs to be tailored to cater for their individual uniqueness and special circumstances. ${ }^{56}$ The determination of these parameters is essentially a domestic matter and the decisionmaking task of governments to allow and regulate FDIs in their home markets by domestic legislation.

Mounting public backlash against the orthodoxy of the post-war FDI policy framework has led some developing countries to reintroduce their FDI regulatory national policies and even withdraw from ISDS to opt for FDI dispute settlement under their domestic laws by national courts. ${ }^{57}$ The mounting evidence of exploitation of ISDS by MNCs in these countries led them to exercise their sovereign right to domestically regulate FDIs and resolve FDI disputes. The European Union has initiated a two-tier international investment court (IIC) (first instance and appellate chambers) since 7 May 2015 to replace ISDS. This proposal has been approved by the European Parliament for recommendation to the $\mathrm{EC}$ in the following terms:

[T]o replace the ISDS system with a new system for resolving disputes between investors and states which is subject to democratic principles and scrutiny, where potential cases are treated in a transparent manner by publicly appointed, independent professional judges in public hearings and which includes an appellate mechanism, where consistency of judicial decisions is ensured, the jurisdiction of courts of the EU and of the Member States is respected, and where private interests cannot undermine public policy objectives. ${ }^{58}$

The proposed IIC is meant to treat both investment protection issues and public interests in host countries on equal footing devoid of any automatic priority of the

56 UNCTAD, 'Investment policy framework for sustainable development' (Geneva, 2015) <https://investmentpolicy.unctad.org/publications/149/unctad-investment-policy-framework-forsustainable-development> accessed 2 May 2020.

57 Bolivia denounced on 2 May 2007, Ecuador on 9 July 2007, and Venezuela on 24 January 2012; Diana Wick, 'The Counter-Productivity of ICSID Denunciation and Proposals for Change' (2012) 11(2) Journal of International Business \& Law 239; Michael Waibel et al (eds), The Backlash against Investment Arbitration: Perception and Reality (Kluwer International 2010).

58 European Parliament Resolution of 8 July 2015, Doc. 2014/2228(INI) (2014), para 2(d)(xv); Piero Bernardini, Reforming Investor-State Dispute Settlement: The Need to Balance Both Parties' Interests' (2017) 32(1) ICSID Review: Foreign Investment Law Journal 38-39; Anne-Karin Grill and Sebastian Lukic, 'Towards a Post-Arbitration Age: The European Commission's Fast-Track Reform of Investment Dispute Settlement' <https://www.lexology.com/library/detail.aspx?g=b519e52db890-4674-9055-23309601b7fd> accessed 16 June 2020. 
former over the latter. This policy has been embodied in the Canada Comprehensive Economic and Trade Agreement (CETA) and the EU-Vietnam Free Trade Agreement (FTA). ${ }^{59}$ UNCITRAL has also been working on a project for the creation and establishment of a Multilateral Investment Court. ${ }^{60}$ These ongoing alternatives to ISDS arbitration are indicative of the fact that ISDS has fallen prey on its own sword. ISDS derives its adjudicative authority from a derivative state consent conferred by host countries in exercise of their sovereignty. Where this state consent is exploited in bad faith, the possibility of its withdrawal and discontinuation may not be gainsaid. ${ }^{61}$ However, despite these emerging developments, the post-war global FDI regulatory policy remains dominant and continues to shackle the regulatory authority and exacerbate existing poverty and inequality in many host developing countries.

\section{A. Curtailing the regulatory power of host developing countries}

The domestic regulatory agency of a host developing country may be reluctant, even unwilling, to make policy and law necessary for its national interest and welfare of citizens for fear of directly or indirectly breaching BIT provisions, which has the potential of exposing itself to international arbitration and huge compensation liability. This chilling effect of FDI disputes hamstrings its legislative freedom and authority. Regulatory chill can only be instilled by foreign investors, but not extended to domestic investors, which is discriminatory. Even the potential risks of FDI arbitration have led some host governments to shelve a Bill in progress and/or amend existing legislation regardless of their adverse effect on domestic public policy and national interest and security. ${ }^{62}$

The scope of ISDS arbitrations of FDI disputes may encompass regulatory issues over and above FDI-specific claims depending on agreed BIT terms and conditions. ISDS awards on such BIT provisions may produce unexpected interpretations and unpredictable outcomes, which can bewilder host countries to understand the operational principles of ISDS arbitrations. It is this lack of understanding on the part

59 CETA ch 8, s F: Resolution of investment disputes between investors and States, Arts 8(18) - 8(45) and EU-Vietnam FTA ch 8, s 3: Resolution of Investment Disputes, Arts 1-34, and Annexes I, II, III and IV.

60 Lino Torgal and Claudia Pinto, 'The Multilateral Investment Court Project: The "Judicialization" of Arbitration' <https://www.lexology.com/library/detail.aspx?g=318efe3f-e1db-473e-b21bde423d8109 d8> accessed 16 June 2020; Catharine Titi, 'The Nationality of the International Judge: Policy Options for the Multilateral Investment Court' Columbia FDI Perspectives, No. 280, 15 June 2020 (Columbia Center on Sustainable Development).

61 Patrick Blyschak, 'State Consent, Investor Interests and the Future of Investment Arbitration: Reanalyzing the Jurisdiction of Investor-State Tribunals in Hard Cases' (2009) 9(2) Asper Review of International Business \& Trade Law 103; Antonius Hippolyte, 'The Unsettled Relationship between International Investment Agreements and the Developing World: A Critical Appraisal' (July 2013) $<$ https://www.researchgate.net/publication/272226466_The_Unsettled_Relationship_between_Intern ational_Investment_Arbitration_and_the_Developing_World_A_Critical_Appraisal> accessed 12 June 2020.

62 Susan Franck and Lindsey Wylie, 'Predicting Outcomes in Investment Treaty Arbitration' (2015) 65(3) Duke Law Journal 459, 471; Miriam Sapiro, 'Transatlantic Trade and Investment Negotiations: Reaching a Consensus on Investor-State Dispute Settlement' (2015) 5 Global Economy and Development 1, 9.

Page $\mid 224$ 
of host countries that often leads them to prefer no-regulation as the safest option to avoid potential ISDS arbitration. This is how the regulatory risk of FDIs is passed on from foreign investors to host countries through the ISDS arbitration process. This process ignores legal pluralism and cripples state sovereignty to flourish the neoliberal pursuit of an internationally homogeneous monist FDI governance policy for a heterogeneous dualist world.

\section{B. The digital divide between FDI exporting and importing countries}

The global business operations of corporate investors have embraced Internet-based digital technologies, which has significantly improved their efficiency in managing FDIs. This technological advancement has seriously impacted the regulation of FDI in technology impoverished host developing countries, which need transition to digital economy as a matter of urgency to boost their competitive edge and avail new opportunities. But the global spread of digital innovation is lopsided and protected. The global policy on technology transfer and FDI policymaking process are yet to be targeted to improve technological capacity in most FDI importing developing countries. These countries find the road to technology is riddled with obstacles created by their capacity constraints, including lack of skill, infrastructure, and human resources with capacity to cope with the technological innovations in FDI exporting countries. Their traditionally weak regulatory systems cannot change fast enough to keep pace with rapid automatisation and digitalisation of complex Internet-specific FDI regulatory matters. Public concerns of negative impacts of digital economy, including the protection of data security and privacy and preservation of socio-cultural values, have but added to hamstring their capacity to regulate the FDI-related risks that may have harmful effects on economies. Consequently, the growing wave of digital economy has, instead of benefiting them, effectively masked their marginalised economic plight.

The current state of affair has contributed to widen further the gap between non-digital capital importing countries and hyper-digital capital exporting countries, exacerbating existing inequality. These challenges lead the FDI seeking developing counties to face two stark choices: rely and depend on technology-intensive MNCs with competing interest or risk further alienation from the global digital economy, the ultimate outcome of the digital divide. ${ }^{63}$ However, limited attempts have recently been made to bridge this digital gap. OECD has launched 'The Going Digital Project' providing digital assistance to its rich members. UNCTAD has also initiated 'eTrade for All' with easy access to sources of financial and technical assistance for improving digital capabilities in developing countries. But with so many developing countries lagging so far behind from the digital ladder and Internet access, their achievement of sustainable development and prosperity through FDI in the one-sided digital economy is increasingly becoming daunting, if not insurmountable.

\section{CONCLUSION WITH RECOMMENDATIONS}


There is an inseparable nexus between the regulation and developmental role of FDIs. Profit maximisation comes foremost at the radar of MNCs to invest. FDI-induced development in host countries does not necessarily occur automatically but requires appropriate check and balance between the protection and development aspects of FDIs. The existing global FDI governance is an asymmetric policy in which ISDS is marked by unpredictable and non-appealable awards, secretive proceedings, inconsistent legal interpretation, appointment of biased arbitrators, exorbitant claims and cost-intensiveness. These features of neoliberalism have infiltrated into the global FDI policy regime to shift the bargaining power to MNC investors and compensatory burden to host developing countries. ${ }^{64}$ It is crucial for host countries to improve their capacity to face the ongoing onslaught of neoliberal and safeguard their national interests. FDI should be treated as merely a means towards the end of achieving sustainable development. Therefore, protection and promotion should be given to only those FDIs that support sustained development, not to those inimical to national interests. The global FDI policy regime can no longer ignore the challenge of achieving tangible FDI-induced sustainable development in host developing countries. Where the domestic laws and policies to attract FDIs are open and generous enough and do not constitute barriers to inbound FDI flows, further regulatory relaxation may militate against development. Instead, a defined national interest test for incoming FDI screening would be of paramount importance to secure the competing interest of host developing countries.

The tension between the competing interests of foreign investors and host countries has persisted despite an evolving backdrop of legislative, judicial, and arbitral attempts to reconcile. FDIs are double-edged impacting host countries positively and negatively, which calls for domestic regulatory intervention to make the positive outcomes outweighing the negative impacts. A regulatory FDI policy need not be FDI protectionism. Rather, it is a pathway to ensure FDI-induced sustainable development that should go together with adequate protection to FDIs. The existing global FDI policy framework warrants a reappraisal to strike a balance between the competing interests of foreign investors and host countries. Corrective liberalisation and preventive regulation of FDI must co-exist to support the exercise of rights and performance of obligations by both stakeholders to achieve their respective purpose of FDI. The policy of maximum protection for FDIs with no specified obligation to contribute to host countries and/or no consequence for failure to deliver is no longer tenable.

The role of FDI towards the goal of sustainable development in host developing countries has steadily been encroaching into the mainstream of international diplomatic vocabulary and policymaking. The Addis Ababa Investment Policy Framework for Sustainable Development 2015 has been embodied in the consensusbased Shanghai Guiding Principles for Investment Policymaking adopted by FDI exporting countries including G20 in July 2016 and endorsed by the G20 leaders in

64 Olivia Chung, 'The Lopsided International Investment Law Regime and Its Effect on the Future of Investor-State Arbitration' (2006-2007) 47(4) Virginia Journal of International Law 953.

Page $\mid 226$ 
Hangzhou in September 2016. The overt recognition in these Principles of the right of host countries to regulate FDIs for legitimate public policy purposes (principle VI) is a positive step. UNCTAD Report 2017 also underscores the need for FDI-led sustainable development in host developing countries and reveals that most modern international FDI agreements embrace sustainable development, preserve the right to regulate and duty to protect, ensure responsible investment, reform dispute settlement, and improve systemic efficiency for promoting and facilitating FDIs. ${ }^{65}$

However, the post-COVID-19 pandemic period is expected to witness a substantial 'fall by up to 50 percent' in inbound FDI movement to advance sustainable economic recovery and development. ${ }^{66}$ This alarming drop will certainly hit hard capital and technology importing developing countries. This predicted collapse of FDIs warrants a searching reappraisal and reform of their existing FDI law, policies, and measures to develop a positive agenda to make them as an attractive destination of FDI. To this end, certain inclusive reformative steps are recommended below for developing countries to consider.

- The liberalised FDI policy has failed to be a catalyst for sustainable development in many developing countries. Host developing countries seeking FDI must have their respective sustainable developmental goal, which requires pre-determined criteria to identify FDI objectives, quantify contribution of FDI, assess the quality of sustainable development, and consequences of failure to deliver. This prior articulation of sustainable development parameters is crucial for not only transparency and fairness of the FDI operation, but also to maximise their unique developmental goal to be set to commensurate individual socio-economic conditions. The advance determination of these domestic requirements is crucial for host developing countries to achieve FDI-induced sustainable development.

- Most developing countries often conclude BITs to increase their FDI entries. But BIT-based FDI encounters a declining trend due to increasing regional free trade agreements, such as TPP and recently concluded the Regional Comprehensive Economic Partnership in the Asia-Pacific, aiming to integrate international investment law, direct and portfolio alike, and replace BIT-based FDI policy and law. Developing countries, particularly non-members of these regional blocs, are often vulnerable in negotiations and the victims of overly imposing BITs due to their unequal and inferior bargaining power. So, they need to be more careful and measured in offering incentives and conferring additional substantive or procedural rights on investors in BITs over and above those already available under the domestic law in negotiating future BITs. It is safe for them to standardise their BIT provisions. Overly imposing BITs will

65 UNCTAD Report 2017 (n 4) 119, 147.

66 Matthew Stephenson et al, 'How the G20 Can Advance Sustainable and Digital Investment' T20 Policy Brief, Saudi Arabia (September 19, 2020) <http://ccsi.columbia.edu/files/2020/09/KPS-T202020-How-the-G20-can-Advance-Sustainable-and-Digital-Investment-Sept.-2020-FINAL.pdf> accessed 30 November 2020. 
expose these countries to compromise their regulatory sovereignty. Investors navigate through these BITs to circumvent local laws to secure favourable outcomes.

- International arbitration has become a dominant private FDI dispute settlement mechanism. FDI disputes are essentially domestic in nature, falling squarely under the domestic law and judiciary of host states, which must be given priority. Such domestic law must contain provisions prescribing the methods and forums of FDI dispute settlement. Effective local judicial remedies are to be improved through specialised courts with greater judicial capacity in speedy commercial dispute settlement. Domestic alternative dispute resolution (ADR) mechanisms with functional competence can act as a reliable nongovernmental commercial arbitration forum. Conciliation or/and mediation by neutral good offices, such as UN Secretary-General or WTO Director-General, may be explored prior to embarking on binding arbitration and requiring the parties to engage in ADR in good faith to resolve their disputes amicably. The exhaustion of domestic judicial and/or ADR remedies must be made a condition for resorting to external arbitration. Developing countries must be cautious in approaching and approving such arbitration as the last resort to limit its exposure to exorbitant damage claims. They should carve-out national policies in sensitive areas from the realms of international arbitration. Given its pro-investor secretive orientation, ICSID arbitration should be minimised in favour of exploring more palatable options, such as ICC and/or UNCTRAL arbitration rules and tribunals having improved transparency, open-hearing, disclosure obligations, time-efficient, and cost-effective for greater accessibility to the public in resolving FDI disputes.

- Investor-state conflict-management mechanisms (CMMs) has been suggested to serve as a safety-valve to obviate outright dispute in many instances ${ }^{67}$ It would allow host developing countries and investors to negotiate their grievances at a very early stage and decisions to be implemented effectively in a non-litigious and cost-effective way. This intermediatory conflict management process has the potential of preventing full-blown legal disputes from developing requiring resort to costly ISDS.

- The operation of FDI projects is usually tilts more towards profit maximisation often at the expense of public interests and policies pertaining to health, occupational safety, human rights, industrial relations, and the environment in host developing countries. Foreign investors cannot conduct their FDI projects in a foreign jurisdiction in defiance of local laws and public policies. Host developing countries must retain and enforce their public policy space and sovereign right to regulate for achieving public welfare objective and regulating the sensitive areas of national significance, such as fiscal interests,

67 Roberto Echandi, 'The blind side of international investment law and policy: The need for investorstate conflict management mechanism fostering investment retention and expansion' Columbia FDI Perspectives No. 290 (November 2, 2020).

Page | 228 
prevention of over-exploitation of natural resources, and land acquisition and resettlement. Public concerns of negative impacts of FDI in this era of digital economy, including the protection of data security and privacy and preservation of socio-cultural values warrant careful consideration in formulating FDI policies.

- FDIs are invariably exposed to non-commercial risks in many developing countries. These uncertainties are beyond the control of foreign investors. Host countries are in a better position to minimise these risk by improving their utility and infrastructural services, energy and water supplies, technologybased customs clearance, administrative professionalism, law and order, accounting practices, and curbing civil unrest, political violence, bureaucratic red-tapes, and systemic corruption.

In pursuit of its post-pandemic FDI-induced economic recovery, the international FDI regime must reorient itself to drive digital transformation and help achieve sustainable development goals in developing countries. It must facilitate necessary technical assistance and specific measures to promote FDIs in digital infrastructural development and digital adoption by traditional non-digital economies to achieve sustainable development in host developing countries. Should this new generation FDI governance eventuate, it would have the potential of easing the tension between the competing interests of host countries and foreign investors and modernising the ailing post-war international policy framework for FDI regulation. 
Dhaka University Law Journal, Centennial Special Issue, Vol. 32(1)

Page | 230 